\title{
EATING BEHAVIOUR OF SHEEP FED AT DAY AND/OR NIGHT PERIOD
}

\author{
T. A. Nugroho, W. S. Dilaga and A. Purnomoadi ${ }^{1}$ \\ Faculty of Animal and Agricultural Sciences, Diponegoro University, \\ Tembalang Campus, Semarang 50275 - Indonesia \\ ${ }^{1}$ Corresponding E-mail: agung194@yahoo.com \\ Received July 16, 2015; Accepted August 25, 2015
}

\begin{abstract}
ABSTRAK
Penelitian ini bertujuan untuk mengetahui tingkah laku makan domba yang diberi pakan pada siang dan malam hari. Materi yang digunakan pada penelitian ini adalah 12 ekor domba jantan dengan bobot badan rata-rata $20,65 \pm 1,89 \mathrm{~kg}, \mathrm{CV}=9,15 \%$ dan umur berkisar 12-18 bulan. Pakan diberikan dalam bentuk pellet sebanyak 5\% dari bobot badan. Rancangan yang digunakan adalah Rancangan Acak Lengkap dan dombadibagi menjadi 3 kelompok perlakuan dengan 4 ulangan. Perlakuan pertama, kedua dan ketiga masing-masing adalah pemberian pakan pada pukul 06.00-18.00 (T0618), 18.00-06.00 (T1806) dan 24 jam (T0606). Parameter yang diamati adalah lamanya waktu aktivitas makan, ruminasi, istirahat, berdiri dan berbaring (menit/hari) serta konsumsi BK ( $\mathrm{g} /$ hari) dan kecepatan waktu makan (g/menit). Data yang diperoleh diolah dengan ANOVA menggunakan uji $\mathrm{F}$ dan apabila terdapat perbedaan dilanjutkan dengan uji Duncan. Hasil penelitian menunjukkan waktu makan $(89,71$ menit/hari) dan konsumsi BK (1034,53 gram/hari) $\mathrm{T} 1806$ berbeda nyata lebih rendah $(\mathrm{P}<0,05)$ dibandingkan dengan T0618 (117,78 menit/hari; 1208,75 gram/hari) dan T0606 (127,5 menit/hari; 1281,63 gram/hari). Data waktu ruminasi, istirahat, berdiri, berbaring serta kecepatan waktu makan menunjukkan tidak berbeda nyata $(\mathrm{P}>0,05)$ pada ketiga perlakuan. Kesimpulan pada penelitian ini adalah pemberian pakan pada malam hari dapat mengurangi waktu makan secara signifikan jika dibandingkan dengan pemberian pakan pada siang hari maupun 24 jam penuh, walaupun hal itu berpengaruh pula terhadap menurunnya konsumsi pakan.
\end{abstract}

Kata kunci: domba, night feeding, tingkah laku makan

\begin{abstract}
The aim of this research was to determine the eating behavior of sheep which fed at day and/or night period. Twelve ram average body weight $20.65 \pm 1.89 \mathrm{~kg}, \mathrm{CV}=9.15 \%$, and age ranged from 12 to 18 months were used in this study. Rams were daily fed pelleted diet at $5 \%$ of body weight (BW) in $100 \%$ dry matter base. Animals were assigned to Completely Randomized Design and divided into three groups for different feeding time treatments. The treatments were day feeding time (feeding allowed from 0600 to 1800; T0618), night feeding (from 1800 to 0600; T1806) and whole-day feeding ( $24 \mathrm{~h}$; T0606), respectively. Parameters observed in this study were duration of eating, rumination, rest, standing and laying activity (minute/day), dry matter intake (DMI, g/day) and eating speed (g/minute). Collected data were analyzed using ANOVA with F-test and if significantly was found were then analyzed with Duncan test. The results showed that eating duration $(89.71 \mathrm{~min} /$ day $)$ and DMI (1034.53 $\mathrm{g}$ /day) on T1806 were significantly lower $(\mathrm{P}<0.05)$ than T0618 $(117.78 \mathrm{~min} / \mathrm{day} ; 1208.75 \mathrm{~g} / \mathrm{day})$ and T0606 (127.5 $\mathrm{min} /$ day; $1281.63 \mathrm{~g} /$ day) but, the other observation of ruminating, rest, standing and laying duration and eating speed were found not significantly different in the all treatments. It can be concluded that feeding at night period can reduce eating time significantly compared to feeding during
\end{abstract}


the day period or 24 hours a day, although it results in decreasing feed consumption.

Keywords: sheep, night feeding, day feeding, eating behavior

\section{INTRODUCTION}

Environment is one of external factors including temperature, humidity, sun radiation and wind movement which directly impact to potential animal production (Ensminger, 1993; Williamson and Payne, 1993; Yani and Purwanto, 2006). Sheep in tropical climate face difficulties from environment such as high temperature and high humidity especially in daylight period because there are extra amount of heat increment (HI) from extra sun radiation (Rianto, 2001; Al Tamimi, 2007). When environment temperature is high and sheep cannot dissipate the heat (heat loss/HL), it will decrease the feed intake (FI) (Bhatta et al., 2006) in order to avoid the excess of HI, so it will result in low body gain (Rianto, 2001). In addition, this condition will make sheep instinctively dissipating the HI by mechanism of thermoregulation (Al Tamimi, 2007; Puchala et al., 2007). This way will reduce sheep productivity because the absorbed nutrition will be used to stabilizing the body temperature, so the maintenance requirement of animal will increase (Ensminger, 1993; Brosh, 2007; Panagakis, 2011).

The ability of animal to take and utilize feed is important to fulfill the maintenance and for production. Generally, FI measured by subtracting the amoun of feed given to the amount of feed remaining, but in terms of animal behavior FI can be measured by observing the time used by animal to consumed the feed (Fraser, 1974; Dartosukarno et al., 2012). Feeding activity has positive relationship with dry matter intake (DMI), feed convertion ratio (FCR), residual feed intake (RFI), but not influenced to body weight gain (Kelly et al., 2009). Response of animal as shown by their behavior may affect to total energy expenditure and feed efficiency due to relationship of chewing activity and total energy requirement (Susenbeth et al., 1998; Bhatta et al., 2006). Feeding time may affect the heat production and heat balance because animal energy expenditure at day period is higher than night period (Brosh et al., 1998; Puchala et al., 2007).

Some researchers suggest to make animal dissipating heat easier by decreasing feed quality or by change feeding time to afternoon (Lowman et al., 1981; Brosh et al., 1998) or night (Hongyngtaracahai et al., 1989). Night grazing or night feeding shows better feed digestibility and utilization than day feeding (Hongyantaracahai et al., 1989), which also reduce energy expenditure for thermoregulation and give better productivity (Lowman et al.,1981; Aharoni et al., 2005).

The aim of this study was to examine efficiency of feeding behavior on sheep fed at night time period compared to day time period.

\section{MATERIALS AND METHODS}

\section{Animals and Feeding Design}

Twelve rams with initial average body weight $(\mathrm{BW}) 20.65 \pm 1.89 \mathrm{~kg}(\mathrm{CV}=9.15 \%)$ and age ranged from 12 to 18 months were used in this study. Animals were assigned to Completely Randomized Design and divided into three groups for feeding time treatments, in which each treatment consisted of 4 rams as replicates. The treatments were day feeding time (feeding allowed from 0600 to 1800 ; T0618), night feeding (from 1800 to 0600; T1806) and whole-day feeding (24 h; T0606), respectively. The rams were fed daily of pelleted diet to fulfill the dry matter requirement at $5 \%$ of body weight (BW). The diet was composed of wheat straw, molasses, dried cassava, rice bran, soybean meal and mineral to make $13.61 \%$ crude protein $(\mathrm{CP})$, $25.71 \%$ crude fiber $(\mathrm{CF}), 2.11 \%$ extract ether (EE), 47.54\% nitrogen free extract (NFE) and $61.08 \%$ total digestible nutrients (TDN).

\section{Feeding Behavior Measurements}

Data of feeding behavior were collected for $3 \times 24$ hours. Parameters observed in this study included eating and rumination time $(\mathrm{min} / \mathrm{d})$, dry matter intake (DMI) total (daily; g) and hourly (per 30 minutes; g) and eating and rumination speed total (daily; $\mathrm{min} / \mathrm{g}$ ) and hourly (per 30 minutes; $\mathrm{min} / \mathrm{g}$ ). Eating and rumination behavior was obtained by manual observation per 5 minutes. Feed intake was measured by subtract amount of feed given to amount of feed refusal. DMI was calculated by multiply amount of feed intake to the percentage of dry matter. Dry matter was determined by dried the feed samples using an oven at temperature $135^{\circ} \mathrm{C}$ for 2 hours. Hourly 
DMI were recorded every 30 minutes by subtracting the amount of feed given to the amount of feed left 30 minutes later. Eating rate was calculated by dividing the amount of feed consumed by the time used to eat.

\section{Data Analysis}

Data were analyzed by ANOVA using the F test for determining significances and if there was found significances then was continued to Duncan test (Gaspersz, 1991).

\section{RESULTS AND DISCUSSION}

The results of day and night feeding on eating behavior are presented in Table 1. The results showed that DMI and eating time among the treatments were different $(\mathrm{P}<0.05)$, while the rest, rumination, standing and laying time, and eating speed among treatments were not different $(\mathrm{P}>0.05)$.

The lowest DMI was found in T1806 which was followed by decreasing their eating time. This was in accordance with the opinion of Kelly et al. (2009) and Dartosukarno et al. (2012) that feeding activity is positively correlated to DMI. These results indicate the day and night feeding affected the DMI and eating time. Theoretically, DMI at night feeding will be greater than of the day feeding considering the night temperature tends to be lower than the day. But, the opposite occurred consumption during the day was higher than of night. In addition, the DMI in whole day (24 hours) feeding was similar to the day feeding, but was significantly different when compared to the night feeding. This fact indicates that the T0606 sheep tend to consume most of their feed during the day and only slightly adding more feed intake at night. Thus, it can be concluded that there was another factors besides the lower temperatures at night which limit the feed intake. The factor which strongly suspected on this limiting feed intake was the lower intensity of light at night compared to the day that stimulated sheep to low activity (rest) including to reduce their feeding activity. The higher light intensity increased the

Tabel 1. Length of Time of Sheep Activity, Dry Matter Intake and Eating Speed

\begin{tabular}{|c|c|c|c|c|}
\hline Parameters & T0618 & $\mathrm{T} 1806$ & T0606 & Average \\
\hline \multicolumn{5}{|c|}{ Temperature $\left({ }^{\circ} \mathrm{C}\right) /$ Humidity $(\%)$} \\
\hline Day & \multicolumn{4}{|c|}{-------------------35.95/55.85-------------------- } \\
\hline Night & \multicolumn{4}{|c|}{ 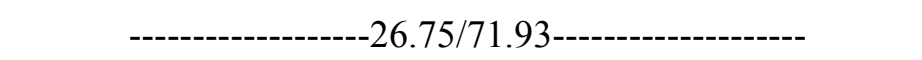 } \\
\hline Whole day & \multicolumn{4}{|c|}{-------------------30.61/63.89-------------------- } \\
\hline \multicolumn{5}{|l|}{ Light Intensity (lux) } \\
\hline Day & \multicolumn{4}{|c|}{------------------------87.15------------------------ } \\
\hline Night & \multicolumn{4}{|c|}{------------------------11.51------------------------ } \\
\hline Whole day & \multicolumn{4}{|c|}{ 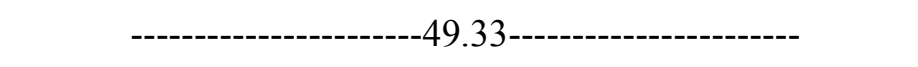 } \\
\hline Dry Matter Intake (g/d) & $1208.75^{\mathrm{ab}}$ & $1034.53^{\mathrm{a}}$ & $1281.63^{\mathrm{b}}$ & \\
\hline Eating Time $(\mathrm{min} / \mathrm{d})$ & $117.78^{\mathrm{b}}$ & $89.71^{\mathrm{a}}$ & $127.50^{\mathrm{c}}$ & \\
\hline Rest Time $(\mathrm{min} / \mathrm{d})$ & 1064.44 & 1084.04 & 992.92 & 1047.13 \\
\hline Rumination Time (min/d) & 257.78 & 266.25 & 319.58 & 281.20 \\
\hline Standing Time $(\mathrm{min} / \mathrm{d})$ & 458.06 & 483.13 & 414.17 & 415.78 \\
\hline Laying Time $(\mathrm{min} / \mathrm{d})$ & 918.94 & 956.88 & 1025.83 & 988.22 \\
\hline Eating Speed (g/min) & 10.62 & 11.64 & 10.25 & 10.84 \\
\hline
\end{tabular}

a,b: Different superscripts in the same row indicate significantly different $(\mathrm{P}<0.05)$ 
feeding activity (Purnomoadi and Rianto, 2002) that was confirmed by the study of Adin et al. (2008) and Nugroho (2012) who found that sheep eat only a small portion of feed at night.

The time allocated for rest and rumination were found not significantly different. Generally, if the amount of feed consumed is fewer, the eating time and rumination to digest the feed is also fewer, and resulting in longer rest time. The possible reason to explain this phenomenon is the digestibility on animal under night feeding might be lower so that need more time to rumination. Sunagawa et al. (2002) reported that animal in a hot environment has a higher digestibility of DM, $\mathrm{OM}, \mathrm{CP}, \mathrm{NFE}$ and neutral detergent fiber (NDF) than of animal in a thermoneutral environment due to the lower frequency and strength of rumen contractions.

Standing and laying time of sheep among the treatments showed not different. This suggested that the activity of animal receiving the day, night or whole day feeding treatment did not change.

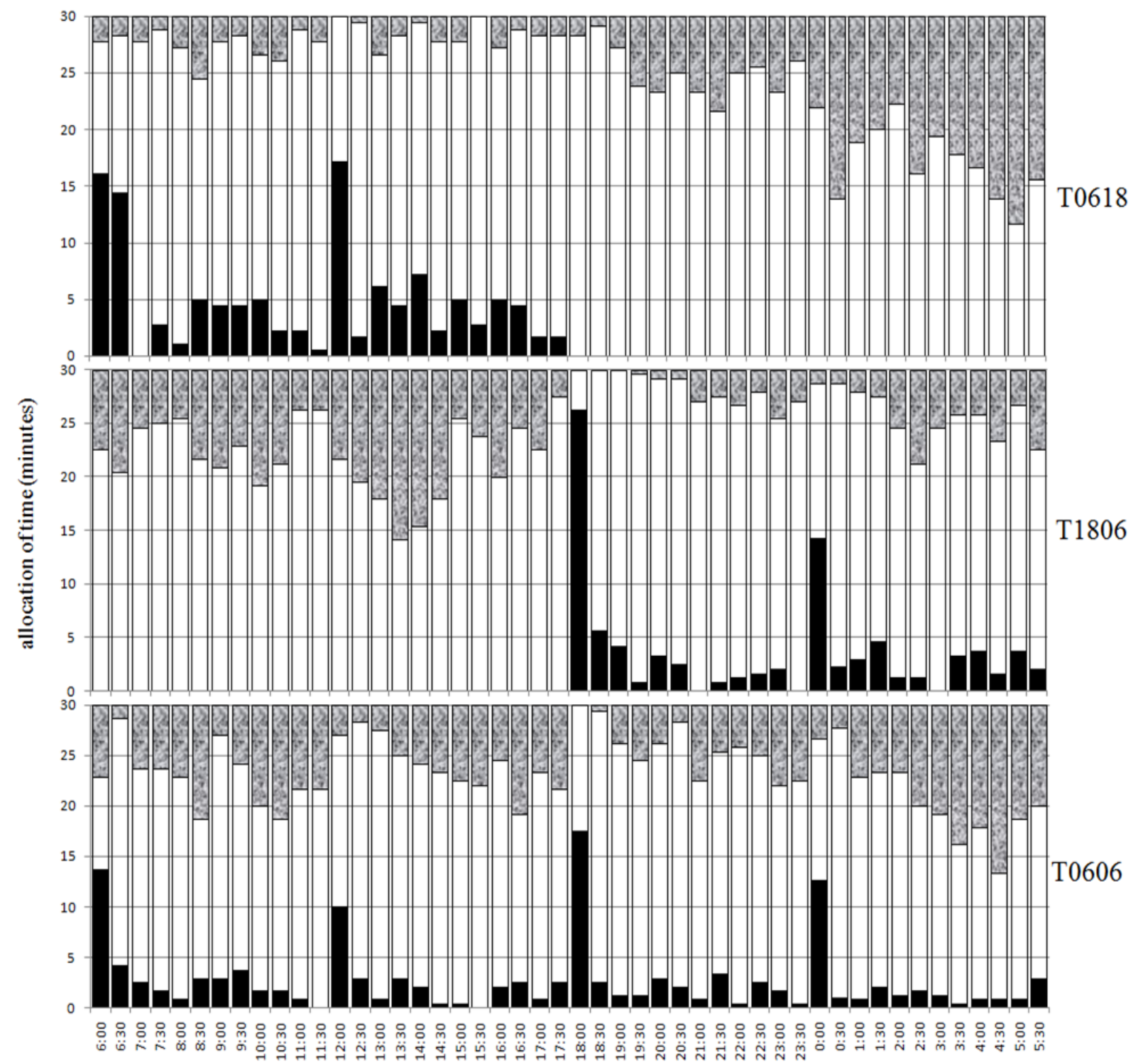

- Eat $\square$ Rest $\square$ Rum

Figure 1. Time Spent for Eating, Rumination and Rest per 30 Minutes among Three Treatment. Eat $=$ eating time; Rest $=$ resting time; Rum $=$ rumination time. 
Standing and laying activities are more influenced by the light intensity than feeding activity or other activity. As discussed above, that one important factor in animal activity is the light intensity.

\section{Eating Efficiency and Diurnal Eating Behavior}

Eating efficiency as shown by eating speed is presented in Table 1, while diurnal eating behavior is illustrated in Figure 1 and 2. Eating speed in all treatments were not different ( $\mathrm{P}>0.05$ ), being $10.62,11.64$ and $10.25 \mathrm{~g} / \mathrm{min}$ for T0618, T1806, and T0606, respectively. The eating speed in night feeding was tended $(\mathrm{P}<0.08)$ to be more efficient to breakdown the diet materials than of day feeding, even though both receiving the same diet. This result indicated that the average amount of feed consumed by sheep per minute did not differ either day or night feeding. However, the interesting phenomenon was observed in the pattern of hourly activity (per 30 minutes) among the treatments. Figure 1 showed that night feeding (T1806) had a tendency to eat faster immediately after feed given than of day feeding time. The time spent for eating at first and second half hour of feed given in T1806 (1800h) was higher than in T0618 (0600h), being $31.88(26.25+5.63)$ and $30.56(16.11+14.44)$ minutes, respectively. The eating time of T1806 was the fastest compare to T0618 and T0606. This was possibly caused by two reasons. First, the sheep in T1806 which fed at night was tried to eat the feed immediately because of afternoon sunlight still remain (Figure 1). Ruminant animals showed a diurnal pattern of eating; they usually consume most of their feed between dawn and dusk or between sunrise and sunset (De Vries et al., 2003). This condition lead the animal to consume as much as possible because animal tend to finish eating activity based on their instinct, marked by the disappearance of the sun light. The second factor was sheep in T0618 and T0606 instinctively did not consuming feed immediately, but it tends to spread the consumption of feed, because T0618 and T0606 had to avoid excessive of heat gain. Animals will reduce the feed consumption because the temperature in the morning until late afternoon tend to be higher, so that it was easier to dissipates the heat and avoid heat stress (Bhatta et al., 2006; Rianto, 2001).

This was proven in the data of percentage feeding time per 30 minutes (Figure 2). T1806 allocates $29.5 \%$ of total time eating in early 30 minutes after feeding delivery, significantly different from the T0606 only spent $13.9 \%$ of total time eating at the same time. Sheep on T0618 spend $14.3 \%$ of their time eating in early 30 minutes after feeding delivery, which is not significantly different from T0606 who spend

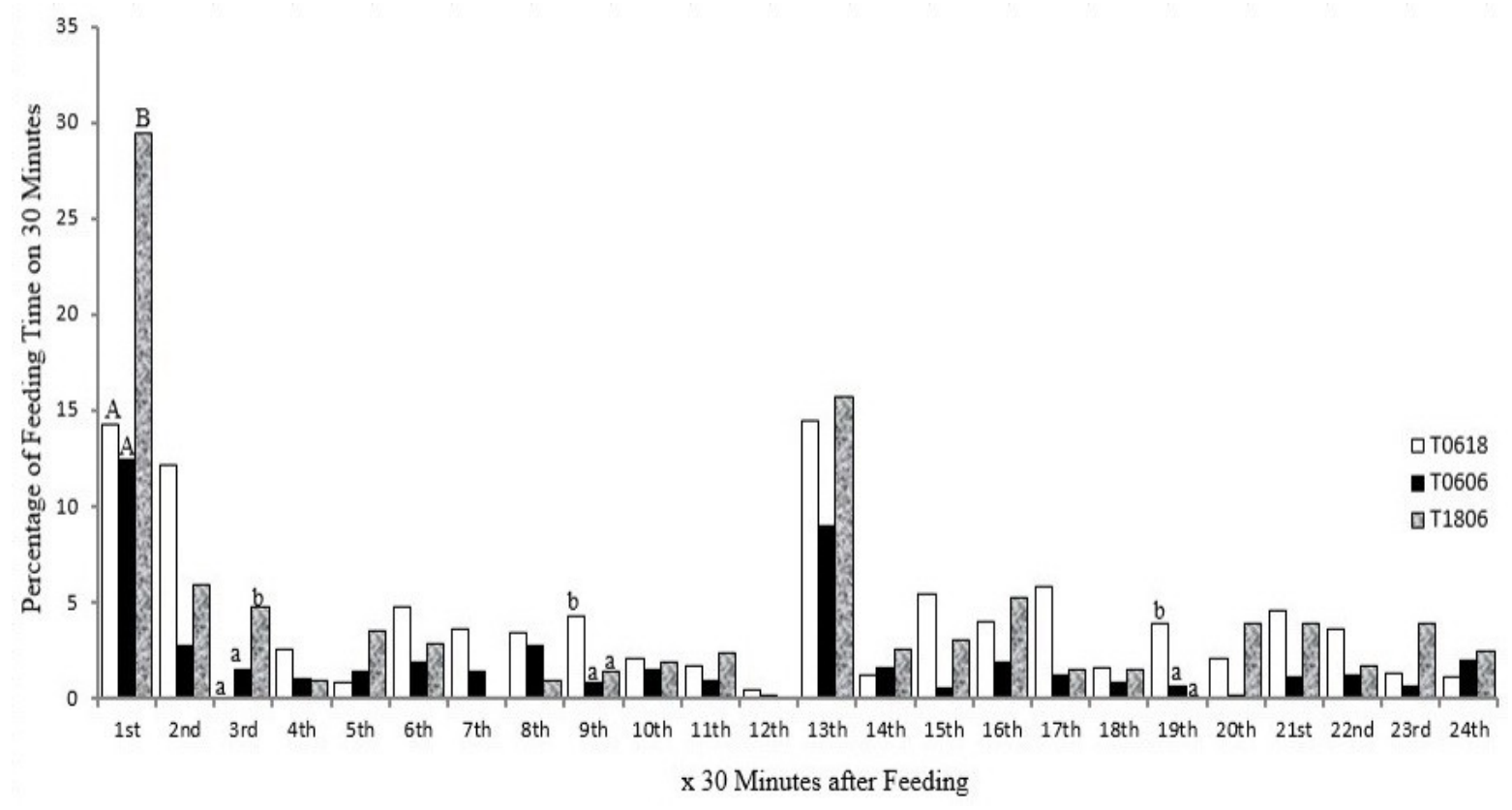

Figure 2. Percentage of Eating Time per 30 Minutes among Three Treatments. The Different Letter shows the Significant Difference at the Same Time 
$11 \%$ of their time eating at the same time. Figure 2 also shows that the livestock on T0618 and T0606 tends to spread the consumption of feed when compared with the T1806. Sheep T1806 uses almost $30 \%$ of their eating time at the beginning of feeding while the rest be shared equally on all the remains of the time.

On Figure 1 also was shown rumination activity on three treatments. Distribution of rumination activity T0618 tend to be few and do not vary at each observation time during the day $(1.99 \pm 1.26)$ where the animals have the opportunity to consume feed, while the observation time in the evenings tend to be higher and more varied than day observation $(8.75 \pm 4.86)$ with the rumination pattern is increased when approaching morning. It can be concluded that at the time when the animals had been active to eat, then the rumination activity will be decline. But the same thing does not happen in animals T1806 that received feed at night. At the night observations, rumination activity of T1806 followed a similar pattern to T0618, although with a shorter time at each time of observation (3.04 \pm 2.43$)$, while during the day observation the rumination activity looks higher and tends to spread with the variation is quite high $(8.06 \pm 3.47)$. This is probably happen because ruminants follows a diurnal pattern typically use more night time to do rumination or rest. While cattle T0606 tends to spread the rumination activity to all observation time at day or night $(6.56 \pm 2.85$ and $6.77 \pm 4.23$; respectively) with the pattern at night tend to be similar to the other treatments that the rumination activity increased when approaching morning.

\section{CONCLUSION}

Feeding at night period can reduce eating time significantly when compared with feeding during the day period or 24 hours a day, although it influenced to decreasing feed consumption. Sheep fed at night period have a tendency to immediately eat the feed at the beginning time of feed was provided, while it did not occur in cattle fed during the day.

\section{REFERENCES}

Adin, G., R. Solomon, E. Shoshani, I. Flamenbaum, M. Nikbachat, A. Zenou, I. Halachmi, A. Shamay, A. Brosh, S. J. Mabjeesh and J. Miron. 2008. Heat production, eating behavior and milk yield of lactating cows fed two rations differing in roughage content and digestibility under heat load conditions. Livestock Science 119: 145-153.

Aharoni, Y., A. Brosh, and Y. Harari. 2005. Night feeding for high-yielding dairy cows in hot weather: effects on intake, milk yield and energi expenditure. Livestock Production Science 95:207-219.

Al-Tamimi, H. J. 2007. Thermoregulatory response of goat kids subjected to heat stress. Small Ruminant Research 71:280285.

Bhatta, R., V. Kumar, M. Sridhar and K. Singh. 2006. Energy Expenditure in Crossbred Cattle Fed Paddy Straw of Different Form. Asian-Aust. J. Anim. Sci. 19(12):17551760.

Brosh, A. 2007. Heart rate measurement as an index of energy expenditure and energy balance in ruminants: a review. J. Anim. Sci. 85:1213-1227.

Brosh, A., Y. Aharoni, A. A. Degen, D. Wright and B. A. Young. 1998. Effects of Solar Radiation, Dietary Energy, and Time of Feeding on Thermoregulatory Responses and Energy Balance in Cattle in a Hot Environment . J. Anim. Sci. 76:2671-2677.

Dartosukarno, S., F. Iskandar and A. Purnomoadi. 2012. Effect of level of concentrate feeding level on efficiency of eating behavior on Ongole Crossbred cattle. J. Indonesian Trop. Anim. Agric. 37(1):22-26.

De Vries, T. J., M. A. G. von Keyserlingk, and K. A. Beauchemin. 2003. Short Communication: Diurnal Feeding Pattern of Lactating Dairy Cows. J. Dairy. Sci. 86: 4079-4082.

Ensminger, M. E. 1993. Dairy Cattle Science 3rd Ed. Interstate Publisher, Danville.

Fraser, A.F. 1974. Farm Animal Behaviour, an Introductory Textbook on the Study of Behaviour as Applied to Cattle. University of Edinburgh, New York.

Gaspersz, V. 1995. Teknik Analisis Dalam Penelitian Percobaan. Tarsito, Bandung.

Hongyantarachai, S., G. Nithichai, N. Wongsuwan, S. Prasanpanich, S. Siwichai, S. Pratumsuwan, T. Tasapanon and B. R. Watkin. 1989. The Effects of Grazing versus Indoor Feeding during the Day on Milk Production in Thailand. Tropical Grassland 23(1): 8-14. 
Kelly, A. K., M. McGee, D. H. Crews, Jr., A. G. Fahey, A. R. Wylie and D. A. Kenny. 2009. Effect of divergence in residual feed intake on feeding behavior, blood metabolic variables, and body composition traits in growing beef heifers. J Anim. Sci. 88:109123.

Lowman, B. G., M. S. Hankey, N. A. Scott , D.W. Deas, and E. A. Hunter. 1981. Influence of time of feeding on time of parturition in beef cows. J. Vet. Rec. 109(25-26):557-559.

Panagakis, P. 2011. Black-globe temperature effect on short-term heat stress of dairy ewes housed under hot weather conditions. Small Rumin. Res. 100: 96- 99.

Puchala, R., I. Tovar-Luna, A. L. Goetsch, T. Sahlu, G. E. Carstens and H. C. Freetly. 2007. The relationship between heart rate and energy expenditure in Alpine, Angora, Boer and Spanish goat wethers consuming different quality diets at level of intake near maintenance or fasting. Small Rumin. Res. 70: 183-193.
Purnomoadi, A. and E. Rianto. 2002. Feeding behavior of buffalo heifers fed rice straw supplemented with urea-mollases. Prosiding Seminar Nasional Teknologi Peternakan dan Veteriner. 30 September - 1 October 2002. Pusat Penelitian dan Pengembangan Peternakan. Bogor. Pp: 79-81.

Rianto, E. 2001. The effect of heat stress and water intake on ruminant production: a review. Jurnal Pengembangan Peternakan Tropis. 26 (3):104-110.

Susenbeth, A., R. Mayer, B. Kiehler, and O. Neumann. 1998. Energy requirements for eating in cattle. J. Anim. Sci. 76:2701-2705.

Williamson, G. and W. J. A. Payne.1993. Pengantar Peternakan di Daerah Tropik. Gadjah Mada University Press, Yogyakarta.

Yani, A. and B.P. Purwanto. 2006. Pengaruh Iklim Mikro terhadap Respons Fisiologis Sapi Peranakan Fries Holland dan Modifikasi Lingkungan untuk Meningkatkan Produktivitasnya Media Peternakan. 29 (1): 35-46. 